\title{
REFLECTION ON ETHNOMATHEMATICS AS A PEDAGOGICAL POSSIBILITY
}

\section{ORIGINAL ARTICLE}

SCHWANTES, Vilson ${ }^{1}$

XAVIER, Márcio Pizzete ${ }^{2}$

SCHWANTES, Eloísa Bernardete Finkler ${ }^{3}$

SCHWANTES, Daniel ${ }^{4}$

\begin{abstract}
${ }^{1}$ Master in Science Education - Mathematics, UNIJUI - RS. Degree and Specialization in Science and Mathematics. Prof. Assistant of the CCA - Center for Agricultural Sciences, Campus of Marshal Cândido Rondon, UNIOESTE, PR - Brazil.

2 Master in Sustainable Rural Development-UNIOESTE, Mathematics Specialist, Physics-UNIPAR, People Management and Special Education with emphasis on Multiple Disability-UNIASSELVI, Graduated in Mathematics with emphasis in PhysicsUNIPAR.
\end{abstract}

${ }^{3}$ Specialization in Exact Science Teaching - Mathematics, Physics and Chemistry. UNIOESTE - State University of Western Paraná. Graduation: Science and Mathematics. UNIJUI, RS. Professor of the State Education Network of the State of Paraná.

${ }^{4}$ Professor of Plant Protection and Human Health at the Pontifical Catholic University of Chile, Department of Plant Sciences, he holds an interdisciplinary position shared between the Faculty of Agronomy and Ingeniería Forestal (FAIF), Faculty of Medicine and Faculty of Chemistry. Research Professor associated with the Study Group on Soils and Environment (GESOMA - UNIOESTE). Master in Agronomy from UNIOESTE, PhD in Agronomy from UNIOESTE (2013-2016) - Sandwich Period (CAPES Scholarship) from the University of Lisbon, at the Instituto Superior de Agronomia (ULisboa). 
JUNIOR, Affonso Celso Gonçalves ${ }^{5}$

KRACKE, Elisa ${ }^{6}$

JUNIOR, Élio Conradi ${ }^{7}$

SCHWANTES, Vilson. Et al. Reflection on Ethnomathematics as a pedagogical possibility. Revista Científica Multidisciplinar Núcleo do Conhecimento. 04 year, Ed. 07, Vol. 11, pp. 148-165. July 2019. ISSN: 2448-0959

\section{SUMMARY}

This article reflects on ethnomathematics as a tendency of teaching that considers the cultural nature of mathematical learning, the social context where this knowledge develops, the role of the teacher in the broader context of human relations by assuming Researcher and mediator conscious of pedagogical practice. The research considers the importance of the history of mathematical knowledge, its multiple relationships with other areas of expertise and its interrelationship with daily activities. The text also reflects on the possibilities and challenges of the school to promote pedagogical

${ }^{5}$ Research Productivity Level $1 \mathrm{C}$ by CNPq in the area of Environmental Sciences with three Postdocs, UEM-PR (Brazil), University of Santiago de Compostela (Spain), UFGGO (Brazil). He is currently an Associate Professor at UNIOESTE-PR and acts as a professor and researcher at the Center for Agrarian Sciences, teaching chemistry. Lecturer in the Master Program in Agricultural Sciences at UEM. He is currently ad hoc consultant to CNPq, CAPES and Fundação Araucária. Acts as volunteer environmental consultant with MP-SP and CONAMA-DF.

${ }^{6}$ Undergraduate student in agronomy-UNIOESTE-State University of the west of Paraná-undergraduate administration-Unip-Universidade Paulista.

${ }^{7}$ Master student in Agronomy (Plant Production) from the State University of Western Paraná (UNIOESTE). Agricultural Engineer graduated from UNIOESTE (2014-2018), acts as a researcher associated with the Study Group on Soils and Environment (GESOMA - UNIOESTE). 
actions that consider interpersonal relationships in the process of $(\mathrm{re})$ construction of knowledge. It beckons to an investigative critical pedagogical work, which in an articulated manner seeks to establish bonds between everyday practices and school mathematics.

Key words: ethnomathematics, social knowledge, mathematical skills, daily activities, pedagogical practice.

\section{INTRODUCTION}

In the day-to-day of the pedagogical process, educators continue to reflect on teaching methodologies and ways of learning. One of the major challenges of the school continues to contribute to the formation of critical, conscious and active citizens in society. A complex task that requires school and education professionals to move beyond curriculum, content and education program.

The world we live in, though we don't realize it, has always depended fundamentally on mathematics. She has always been and is present in practically everything that surrounds us. Its applicability is relevant even in other sciences, as D'ambrósio affirms (1996, p. 31). "The tendency of all sciences is increasingly matematizarem because of the development of mathematical models that develop natural phenomena in appropriate ways."

As we see, mathematics is impregnated throughout the social environment of the human being and is evidenced by each new learning. All current professions appropriate the mathematical knowledge to create, maintain and sustain rules, formulas and conducts. The bricklayer, the seamstress, the cook, the engineer, technicians of all professions and professionals from all sectors of human activity dominate some mathematical knowledge, but have not always learned the calculations to solve their problems in the banks School. 
For Rosa Neto (2002), there is a significant relationship between mathematics and culture, both as a result of our adaptation according to our survival needs through the times, representing both, an empirical, systematic and Scientific.

To work Ethnomathematics in the school space, according to D'ambrósio (2008), is to contribute to the new generations to know and recognize a much more cultural mathematics, linked to the daily life of several ethnic groups. For D'ambrósio and Rosa (2016), this is a didactic posture that seeks an improvement in the teaching-learning process of the discipline with the incorporation into the mathematical curriculum of knowledge arising from the life of the student and human values, such as, for example, the cooperation, solidarity and ethics. They are knowledge that promotes appreciation and respect for the different ways that mankind uses daily to explain, understand, understand and deal with the problem situations faced in everyday life.

With this awareness regarding the importance and role of mathematics in the development of citizens and society, this article, in addition to reflecting, seeks to disseminate ethnomathematics, believing that it as a pedagogical proposal can greatly contribute to Mitigate the learning difficulties and lack of interest of many students in the study of the discipline.

In our understanding, an educational work centered on this perspective, makes the student feel safer from his own ability to build mathematical knowledge, in the search for solutions to the problems he encounters within his daily life. For D'ambrósio (1996), however, it is necessary that the teacher adopt a new posture in the classroom, seek a new paradigm that replaces the already worn-out teaching-learning based on an obsolete relationship of cause-effect.

Pompey and Monteiro (2001, p. 14), warn, ponding that,

Paradigm shift, however, is a complex process; It is necessary to want to change and believe that this is possible. More than finding that we need to change, it is necessary to have the conviction that there is always a new way of teaching, that it is always possible to change. 
The authors emphasize that working pedagogically in this perspective requires the teacher to understand and clarify the scope of their role, as well as the importance of the mathematical content with which they work with the students. In theory, it is necessary to understand the student in an integral way, seeking to identify their development needs at the intellectual, physical, emotional, social and cultural level. Therefore, they pointed out that,

Current teachers face a great challenge: educated in a fragmented process, they will have to overcome the limits that this formation imposes on them and extrapolate the boundaries of content seen in a partial and a-historical way (POMPEU and MONTEIRO, 2001, p. 15).

The task of teaching and learning, in this approach, is in fact different from that traditionally known. It is part of what we believe to be consensual, that is, that all cultures and peoples have developed their own ways of explaining and modifying their own reality. These knowledge and making present in every process of human development, proper to each culture, are in the process of course, are dynamic, in the phase of evolution and constant growth, thus contributing in the elaboration of systeted knowledge.

D'ambrósio (1993) emphasizes that people have a cultur[etno]e, deal with and explain their own [matema]culture, however, each in their own way and form[tica]. This finding resulted in the name Ethnomathematics, which in turn takes into account the explanations of the communities, dripping them with the universal forms of knowledge. It is a fact that every child before arriving at school knows how to deal perfectly with their reality, which is constantly evolving.

According to the author, Ethnomathematics is part of the principle and idea of incorporating the models linked to the tradition and culture of children, recognizing them as valid for fulfilling their purposes. Thus, ethnomathematics messes with the curiosity of the child, turns first, to the environment where she lives, fulfilling a task that the school has forgotten: to liberate and develop the creativity of students through projects Investigative. 
This pedagogical perspective is the so-called ethnomathematics, a tend ${ }^{[8]}$ ency of the teaching of mathematics that considers in its pedagogical practice the social and cultural aspects of mankind. It is characterized as a teaching tendency that brings to the discussion and seeks to reflect on the various forms of Matematizar present in our socio-cultural reality.

It proposes a critical education, whose foundation is supported in the studies and writings of Ubiratan D'ambró ${ }^{[9]}$ sio, which point to a methodological proposal of mathematical education that values the experiences of the students. A vision with features that permeate the processes: anthropological, social and political, bringing to the discussion the local culture of each social group, as a human activity culturally determined by the context where it is performed.

It is in this aspect that ethnomathematics, in recent decades, has been consecrated nationally and internationally as a didactic-pedagogical proposal for teaching mathematics discipline. According to D'ambrósio (2001) "Ethnomathematics is the mathematics practiced by cultural groups, such as urban and rural communities, groups of workers, professional classes, children of a certain age group, indigenous societies, and so many others Groups that are identified by the objectives and traditions common to the Groups "(p. 9).

It is, according to the author, a tendency of teaching where knowledge manifests in a holistic way, that is, it allows the different cultural groups to know, understand and explain their world, using mathematics, developing Ability to manage and interfere, through it, in its reality. It beckons to the possibility of constructing a school curriculum that incorporates the socio-cultural life of students in pedagogical practices, as one of the forms of social inclusion.

In the words of D'ambrósio (1993), "Ethnomathematics is a program that aims to explain the processes of generation, organization and transmission of knowledge in various cultural systems and the interactive forces that act in and between the three Processes" (p. 7). 
In this teaching tendency, the curriculum is dynamic, contextualized, recognizes the cultural and social plurality of students, allows the student to become an active subject, participative in the process of transforming his local, regional and global environment.

In relation to the Ethnomathematics program, D'ambrósio (2001, p. 17) also ponders that,

The great motivator of the research program that I call Ethnomathematics is to seek to understand the mathematical know-how throughout the history of mankind, contextualized in different groups of interest, communities, peoples and nations.

Pompey and Monteiro (2001), regarding the adoption of a pedagogical practice that takes the know/do to the classroom, argues that he

It is imbued with certainties that are not "given" by science, but rather by values, traditions and respect for those who teach. Thus, it has an "emotional certainty" confirmed by experience, different from the "scientific certainty" that, in general, is susceptible to rational demonstration and mathematics, although, when taught, also instituting emotional values, present in the person of Teacher (p. $134-135)$.

In the pedagogical action, the relationship to be established between the processes of teaching and learning is dialogical, because it is the context in these interactions that favors learning possibilities. In this dynamic, bringing ethnomathematics and knowing/doing to the classroom means recovering the experiences and knowledge present in the daily activities of different working classes, in an effort to overcome the scientificism of knowledge Academic.

However, Pompey and Monteiro (2001), in relation to working in the classroom the formal and informal knowledge, pointed out that,

[...] It is necessary for a group to know and acknowledge the limits of their knowledge to go beyond and seek the new with consciousness, knowing 
and discussing the importance and validity of this new one. Only in this way will he know how to choose when and what knowledge to use (p. 53$54)$.

In schools in general, it is taught and learned only mathematics dictates as official, while in everyday acti[comercias, agrícolas, de prestação de serviços, entre outras]vities, they apply and use mathematical knowledge not officially recognized, but constructed socially, validated and Valued by society.

In short, sometimes it seems that citizens live with the existence of two mathematics: the school, [oficial] lived within schools, theoretical, abstract and selective and that of real life that meets the emerging needs of citizens. It is perceived that this "other mathematics", rarely accepted by the school, shows itself practical, dynamic and tuned with all sectors of society, being widely used in the routine activities of citizens.

According to D'ambrósio (2001), Ethnomathematics, in addition to not denying formal mathematics, seeks to bring to discussion each form of Matematizar, analyzing argumentatively and reflexively each context where mathematics is inserted. It understands and discusses the various forms of Matematizar, provided that the purposes of each context are fulfilled, of each group of equals in their specific situations.

Therefore, working mathematics in an ethno approach ${ }^{[10]}$, as D'ambrósio proposes (1993), requires the educator to learn how to deal with the different culturally constructed knowledge and circulate among the students. It proposes that the school rethink its practice, in harmony with the aspirations and daily needs of people, rescuing the social function of mathematical knowledge.

In this dynamic, the educator must be open to changes in the way of acting and working. You need to listen to the experiences that students bring from home, from their community, from the relationships established between them, seeking from this dialogical-interactive process to work the mathematical content. And, in addition to incorporating new methodologies in their practice, constantly analyzing and evaluating 
their practice, improving pedagogical actions previously experienced. Finally, it needs to construct the mathematical knowledge from the personal experiences of those involved in the educational process.

Thus, according to Professor Ubiratan D'ambrósio, the practice of ethnomathematics in the classroom, suggests following a much broader path of socializing and sharing different knowledge.

By practicing Ethnomathematics, the educator will achieve the great goals of mathematical education, with distinct perspectives for different cultural environments and production systems. It is justified to insert the student in the production process of his community and social group and evidences the cultural and historical diversity in different contexts (D'ambrósio, 2008, p, 8).

\section{JUSTIFICATION}

In schools, in a considerable percentage, it is perceived that the teaching-learning process of mathematics continues to be immutable, that is, the teacher continues to bring the information ready, the student receives them passively, transparently, in these cases, An accentuated conformism and historical determinism. In practice, there is also a disjointed methodology between what is learned in school and what society really demands from its citizens.

According to Santos (2016):

The lack of contextualization in the teaching of mathematics can cause the discouragement of the discipline, resurrecting the traditional methods that conceptualize mathematics as a science that brought all things ready, as if it were a ready knowledge and Over. (p. 5).

A teaching that leads the learner to a mechanical learning. Furthermore there are still those who believe that mathematical knowledge is possible only for privileged, not 
accessible to all, which according to Ubiratan D'ambrósio is comparable to the system of "caste" applied to some countries.

[...] Some mathematical educators see mathematics as a privileged form of knowledge, accessible only to some especially gifted, and whose teaching should be structured, taking into account that only certain minds, in some "special" way, can Assimilate and appreciate the mathematics in its fullness[...]. (D’AMBRÓSIO, 1996 p.9).

In an attempt to minimize this situation and bring motivation and joy to the classroom, we seek through this bibliographic research, both a more contextualized mathematics for the students, and a methodological path that provides better results . A teaching alternative that allows more signification for the contents of mathematics studied. Something motivating, attractive and that really serves the learner in a way that allows him to solve situations-problem in a contextualized way, infer and make decisions in the face of his reality, understanding that, including formal mathematics is alive, is present In our day to day.

A mathematics taught in school that is present in the reality of the students ' life, which seeks interaction between school and community, in the possibility of being a tool for transforming the social environment. A knowledge whose construction and understanding is not only possible for mathematicians, scientists, masters or doctors, but also for social groups that develop or use in their work activities skills to measure, calculate, draw, create or Play, according to your interests and needs.

That allows students to become singularized and reflexive, emancipated, confident and interactive subjects in the community through the knowledge acquired. Giardinetto (1999), in his writings ponders that the subject will only become a participating citizen of his society as he "appropriating himself of Cultural instruments" (p. 73).

We know and agree that mathematics is a science present both in the daily lives of citizens and in research centers. Therefore, considering this scope we cannot limit the teaching of this discipline to a simple memorization of rules, techniques and the formal 
knowledge of definitions, because "... Teaching is not transferring knowledge, but creating possibilities for its own production or its construction. " (FREIRE, 1996, p. 52).

Teaching mathematics from the perspective of ethnomathematics becomes impossible without rescuing the knowledge and values that students bring from home. In order for this act to be realized, it is indispensable for the teacher to listen to his students, as is indispensable to the student who speaks to his teacher and his colleagues.

According to educator Paulo Freire,

"The construction of dialogical relations under the foundations of the universal ethics of human beings, as a specific human practice implies the awareness of human beings, so that they can actually insert themselves into the historical process as subjects who make their Own history. " (FREIRE, 1996, p10.)

The mathematical educator Paulus Gerdes, in his various publications always adopts a discourse that rescues the mathematical traditions of the cultural groups, that before the colonization were being according to him "hidden" and imposed by Eurocentric conventions in Society, as well as in the school space.

Thus, in this perspective, (GERDES, 2010, p. 142) reports that

Ethnomathematics is the research area that studies the multifaceted relationships and interconnections between mathematical ideas and other cultural elements and constituents, such as language, art, crafts, construction and education. It is the research area that studies the influence of cultural factors on the teaching and learning of mathematics.

According to the author (2010, p. 142-143) "Ethnomathematics shows that mathematical ideas exist in all human cultures, in the experiences of all peoples, of all social and cultural groups, both of men and women." Within this cultural perspective, it is also evidenced that 
[...] All peoples of all time can contribute to this universal mathematics. All peoples have the right to be able to learn and enjoy the accumulated knowledge and to be able to contribute to their enrichment. Here lies an ethical and moral dimension of Ethnomathematics reflection. (GERDES, 2010, p.144)

Several authors have already reported and by our professional experience we have also noticed that the different forms of Matematizar are so present in the daily lives of citizens, that many people use them in their daily chores, even though they never attended a school. This knowledge, sometimes acquired empirically, is of extraordinary value and richness so significant that many do not always have the sensitivity to perceive them. We shared with Pompey and Monteiro (2001) when they postulate that,

"Man relates to the world around him, understood this as world-life, that is, the world in which people are inside, which educcates us through influences that reach us through our relations with him" (p. 21).

However, it is not intended, in this pedagogical perspective, to propose a new mathematics, but to reflect on the possibility of identifying, in the different cultural groups, their modes of Matematizar, valuing and considering their ways of calculating, Know, explain and understand the world that surrounds them, enriching in this dynamic, school mathematics. As D'ambrosius (2001) reports, it is a mathematics that "... It is part of the daily ", of the Know-how (p. 25). In fact, a pedagogical proposal that works in an integrated way the formal and informal knowledge.

We believe that from the moment we think of Ethnomathematics as a pedagogical alternative that considers mathematics in different social, cultural and historical environments, new methodologies are incorporated in teaching. It becomes the school mathematics an instrument to explain and understand the development and production of the knowledge generated in these different contexts, motivating the students.

Understanding the knowledge that is developed within a given community is to understand ethnomathematics in this environment, that is, to look back at the various 
forms of manifestation of knowledge, not only of mathematical knowledge, but The knowledge of life, of organization, of the construction and structuring of these knowledge and making that they are the birth of these people.

However, many mathematics educators, perhaps due to their university education centered on the Technicist line, show difficulties in breaking with the old paradigm and adopting a teaching methodology that interconnects school mathematics with the mathematics of Life. This fact becomes an obstacle for the classroom to be transformed into a space for discussion and critical analysis of socio-culturally constructed knowledge. For Pompey and Monteiro (2001, p. 19), it is necessary to look for ways to overcome existing conflicts, because "we live a moment when the fragmentation of knowledge limits the understanding of reality".

We need to be confident that what students do and learn at school can be more aligned with the actions and needs of the various sectors of human activity outside the school walls. The educator simply incorporates and brings to the classroom these socially constructed knowledges. We share in this research with the writings of D'Ambrosio and Rosa, as they consider Ethnomathematics as a research program in history and philosophy of mathematics, with pedagogical implications,

So, this research program represents a research methodology that seeks to analyze local mathematical practices, as it seeks to value, disseminate and respect mathematical knowledge (ideas, notions, procedures, processes and practices) that Originate in various cultural contexts throughout history (D'ambrósio and ROSA, 2016, p. 17).

A pedagogical work centered on this perspective, values the human being and his informal knowledge constituted in and by the culture where he lives, can be the beginning of a change in the teaching of this discipline. According to D'ambrósio (2001), a teaching that "reveals practices seized outside the school envi[pode]ronment contribute to a critical view of reality" (p. 23). 
The school as an institution that represents the continuation of the family in its broader context, must understand that the whole teaching-learning process that part of the previous experiences of citizens, of the forms of matematizar experienced by students outside the School, enriches the Educational act. In the words of Giardinetto (1999) "The Daily life itself needs interferences of the non-quotidian" (p. 7).

In this sense, it would leave to work the official mathematics as the only mathematics that deserves attention. We would consider and bring to the discussion the experiences and knowledge of students prior to the school phase. The school by dialogically merging all these knowledges transforms the classroom into a permanent learning laboratory.

In this trend, one of the educators ' roles is to stimulate the students ' natural desire to investigate the different mathematics used in the various cultural groups. By understanding the processes of Matematizar of each culture, they compare these knowledge with formal knowledge, systate and validated by the school, having the opportunity to organize their own thinking, comprising through this reflection the cultural importance and social of every mathematical knowledge circulating in the world of life. In the words of D'ambrósio (2001), it could be better understood that "the behavior of each individual, associated with his knowledge, is modified by the presence of the other" (p. 32).

According to D'ambrósio (1993), teaching mathematics in this conception means respecting what the student already knows, consists in recognizing the historically constructed knowledge in cultures, establishing dialogical moments of critical questions that renew and The previous knowledge of all participants in the learning process.

For D'ambrósio (2001) It respects and values each of the existing mathematics, and "... It is the communication that allows to define strategies for common action "(p. 58). The school, by dialectical reflec ${ }^{[11]}$ tion, explicates the modes of production of mathematical meanings produced outside its specific context. In this approach it is as if the school mathematics joined with the forms of matematizar of the surrounding 
world, rather than replacing it. While school mathematics ignores or does not discuss this diversity of knowledge, produced in the culture of each people, ethnomathematics values and brings to the debate these differences, recognizing their mathematical models and the knowledge linked to them .

According to D'ambrósio (2001), while traditional mathematics and its teaching seek to universalize the concepts, making them increasingly abstract and generalizing, Ethnomathematics seeks to rearrange them, making them more specific and applicable to Context of the lived reality. It proposes, in summary, a more coherent way of walking. It seeks to bring mathematics fro[da escola]m books to life and life to school, recognizing that both have a history and importance for understanding reality in all its dimensions.

The basic idea of this tendency of teaching mathematics, according to D'ambrósio (2001), is to consider the experiences of students, relatives, groups of equals, different cultures and all forms of self-matematizar of each people. They are knowledge produced by the practical need to solve specific problems of fairers, small farmers, bricklayers, carpenters, indigenous groups, settlers, etc. They are different knowledge produced by different groups to elucideal problem situations.

For Pompey and Monteiro (2001), a pedagogical practice that at the same time opposes the fragmentation of knowledge, is characterized by situating the historical knowledge culturally and opportunizing men to the rescue of their critical reflective dialogical capacity. It understands, according to the authors, the human being in its entirety and the knowledge in all its complexity.

In the words of Pompey and Monteiro (2001), a teaching that places "man and not capital as the central value of social relations" (P. 26). According to D'ambrósio (2001), a work centered on this perspective requires educators to have a good dose of humanism, because "the student is more important than programs and content" ( $p$. 86). 
Mathematics worked on an ethno approach brings to the classroom experiences that require communicability and argumentative dialogue. This didactic posture, in turn, leads those involved with the educational process to a personal and collective growth, made possible by the permanent reflective action of both, and of both practices.

Together, teachers and students teach and learn simultaneously, know the world in which they live critically and build relationships of mutual respect, justice, constituting a real climate of discipline, by dialogical relations, making the classroom a challenge Interesting and challenging to all involved. "He who teaches learns when teaching and who learns teaches in learning" (FREIRE, 1996, p. 38).

According to Giardinetto (1999), "The teacher can and should use daily knowledge as a point of support for the teaching-learning process" (p. 68), bringing the student into the field of argumentation, developing the habit of critical reading, research, Questioning, of creativity, indispensable for citizen training.

By launching this look on their practice, the students ' previous knowledge is valued and others are formed, always from the known. The important thing is the establishment of bonds of knowledge of the community with the knowledge of the school and the knowledge of the school with the knowledge of the community. Through this establishment and these relationships it is possible to attribute meaning to both knowledges. For D'ambrósio (2001), in this context, knowledge presents a dynamic character, always open to new approaches.

For Freire (1996) The role of the teacher is linked to the conception that teaching is not transferring knowledge, but creating conditions for its construction. It means recognizing that together, students and teachers learn in the classroom, since they all bring many knowledge of the school and non-school experiences they have experienced during their existence.

We believe that Ethnomathematics can assist each educator in this pedagogical possibility of replacing the routine actions of "giving ready classes" by a posture that (re) orient the student's learning in the construction of his own knowledge, fruit of 
Interaction between subjects in this dialogical process. Even because the society of knowledge in which we live, demands today a holistic stance in the formation of its citizens, who are able to interact with dynamism in all contexts, construct new meanings for mathematics, exploring Different forms of situations-problem of various human activities.

\section{GOAL}

To contribute from the reflection to the mathematics educator to adopt an investigative critical posture in relation to the teaching of mathematics, from the perspective of initiating his teaching activity through the establishment of bonds between daily mathematics and School mathematics.

\section{METHODOLOGY}

The theoretical inspirations of this article are due to readings and reflections on mathematics Education, Ethnomathematics and the intercultural perspective of teaching. The writings seek to reflect on the ethnomathematical approach in the perspective that a teaching based on the students ' previous knowledge, valuing their culture and their modes of Matematizar, will be an aggregating factor of knowledge, giving a more humane character For discipline.

\section{EXPECTED CONTRIBUTIONS}

May it be perceived, according to D'ambrósio (2001), the importance of ethnomathematics in the formation of the student, since its cultural and anthropological bias points to the path that leads to respect for the differences, understanding and inclusion, so necessary to our reality Social.

That teaching mathematics in the classroom, from this pedagogical perspective, allows an effective dialogue between the mathematical knowledge produced in different contexts and that teachers reflect more on the cultural diversity of the discipline and its Importance for Systate education. 
That from this reflection the pedagogical practice in the classroom can be reoriented to the development of the full citizenship of the students. That, according to Pinheiro and Rosa (2016), the:

[...] Mathematics teachers immerse themselves in the cultural dynamics of students and use teaching and learning strategies that value the cultural dimension in the classroom, so that an inclusive mathematical education can be developed that could effectively Contribute to social transformation (p. 79).

That this effort can contribute to new elements for teaching the discipline of mathematics, allowing in the classroom to study more and more mathematics and reality, as ways of knowing and interpreting each context, in a process in which the teacher will be Constantly (re) producing, (re) constructing, (re) meaning knowledge and knowledge.

We also hope that readers perceive the possibility of inserting in the teaching of mathematics a differentiated look at the reality and on the mathematics itself and that this look corrode with the mathematical learning of the educating so as to take you to participate in Discussions about mathematics inside and outside the classroom.

We want the classroom, based on the teaching methodology, to begin to incorporate/analyze in the pedagogical process, problem situations whose resolution considers both formal mathematics and informal mathematics. May the discipline be seen as a human activity, motivating even more the interest of the students.

We emphasize that it is not a question of replacing mathematics with another, but of respecting the different modes of Matematizar in different contexts, within the purposes to which they are proposed. Thus, we believe that this educational approach can refer us to a contextualized education, enriched, motivating the participants to be part of the process.

In the words of RAM one, 
[...] Teaching mathematics in this conception will allow the student to link the concepts working in class to their daily experience, according to their natural, social and cultural environment. It is not about rejecting academic mathematics, but rather incorporating values that are experienced in group experiences, considering the historical-cultural bonds (CARNEIRO, 2012, p. 3).

Finally, it intends to contribute to the Constitution of the researcher Professor of his practice, arousing him/her to learn in a continuous way to be a teacher, according to the current educational needs, transforming the classroom into a learning environment Democratic exchange of knowledge, rescuing historical-socially constructed knowledge of mankind.

\section{BIBLIOGRAPHICAL REFERENCES}

CARNEIRO, K. T. A. Cultura Surda na aprendizagem matemática da sala de recurso do Instituto Felipe Smaldone: uma abordagem etnomatemática. Anais do 4ํㅡㄹ Congresso Brasileiro de Etnomatemática. Belém, PA: ICEm4, 2012.

D'AMBRÓSIO, Ubiratan. O programa Etnomatemático: Uma síntese. Acta Scientía, v.10, n.1, Jan/jun.2008.

Etnomatemática - elo entre as tradições e a modernidade. Coleção Tendências em Educação Matemática, 1. Belo Horizonte: Autêntica, 2001, 112p.

Da realidade a ação: Reflexões sobre a educação e matemática. Campinas: Unicamp, 1996.

Etnomatemática: Arte ou técnica de explicar e conhecer. Editora Ática, Série Fundamentos, 2. edição, São Paulo, 1993.

D'AMBROSIO, U.; ROSA, M. Um diálogo com Ubiratan D'Ambrosio: uma conversa brasileira sobre etnomatemática. In BANDEIRA, F. A.; GONÇALVES, P. G. F. (Orgs.). 
Etnomatemáticas pelo Brasil: aspectos teóricos, ticas de matema e práticas escolares. Curitiba, PR: Editora CRV. 2016. pp. 13-37.

FREIRE, Paulo. Pedagogia da autonomia: Saberes necessário a prática educativa. São Paulo: Paz e Terra, 1996.

GERDES, Paulus. Geometria dos Trançados Bora na Amazônia Peruana, Livraria da Física, São Paulo, 2010, 190 p. São Paulo: Editora Livraria da Física, 2011, 190p.

GIARDINETTO, José Roberto Boettger. Matemática escolar e matemática da vida cotidiana. Coleção polêmicas do nosso tempo, autores associados, Campinas - São Paulo, 1999, 128p.

MONTEIRO, A.; Pombeu, G. Jr. A matemática e os temas transversais. Editora Moderna, São Paulo, 2001, 160p.

PINHEIRO, R. C.; ROSA, M. Uma perspectiva etnomatemática para o processo de ensino e aprendizagem de alunos Surdos. RPEM, v. 5, n. 9, p. 56-83, 2016.

ROSA NETO, R. Didática da matemática, São Paulo: Ática, 2002.

SANTOS, Lijecson Souza dos. Contextualização Matemática Em Situação De Ensino E Aprendizagem No Eja. Disponível em: https://editorarealize.com.br/revistas/cintedi/trabalhos/TRABALHO_EV060_MD1_SA 18_ID 492_23102016194610.pdf. 2016.

8. In this investigative work, used to designate methodological referral that can be developed from the perspective of the investigation of the conceptions, traditions, and mathematical practices of a social group, through which the group interprets and codifies its Knowledge.

9. Ubiratan D'ambrósio, professor, mathematical educator and researcher at the Paulista State University (UNESP). Rio Claro Campus. Institute of Geosciences and Exact Sciences (IGCE). He is Professor emeritus at the State University of Campinas/UNICAMP. He has published studies in: History and Philosophy of 
mathematics, history and philosophy of Sciences, Ethnomathematics, ethnoscience, mathematical Education and transdisciplinary studies.

10. The ethno approach refers to several perspectives in circulation regarding this area, which is not, to date, theoretically crystallized. The educators and researchers involved in this issue decided to give time for the explorations to advance and thus contribute to a possible theoretical elaboration of ethnomathematics. It is possible that this development broadly includes the various perspectives in circulation.

11. Dialectic in this reflection, expresses the art of searching for dialogue, through argumentation and counter the expansion of ideas and concepts involved in the discussion. In the analysis of facts and situations-problem that allow the development of thought, teacher and student have equal dialogical participation, one always listening to the other, (re) building together their learnings.

Submitted: June, 2019.

Approved: July, 2019. 